\title{
The safety of isotretinoin treatment in patients with bone fractures
}

\author{
Bartosz Miziołek ${ }^{1}$, Beata Bergler-Czop², Anna Stańkowska¹, Ligia Brzezińska-Wcisło² \\ ${ }^{1}$ Department of Dermatology, Andrzej Mielęcki Silesian Independent Public Clinic, Katowice, Poland \\ ${ }^{2}$ Department of Dermatology, School of Medicine, Medical University of Silesia, Katowice, Poland \\ Adv Dermatol Allergol 2019; XXXVI (1): 18-24 \\ DOI: https://doi.org/10.5114/ada.2019.82822
}

\begin{abstract}
Isotretinoin is widely applicable in dermatology, although it may develop severe side effects in the skeletal system. An intention of this review was to establish the safety of oral isotretinoin in patients with bone fractures. Both MEDLINE/Pubmed and SCOPUS databases were searched to investigate the influence of isotretinoin on the skeletal system. The drug shows a strong osteoporotic activity in rats whereas this effect is milder in humans. Biochemical markers of bone turnover remain unchanged except for serum calcium in patients receiving a high dose of isotretinoin. An excessive intake of vitamin A may impair functioning of vitamin D especially in people with a vitamin D deficiency, therefore a similar side effect may also occur in patients on isotretinoin treatment. We suggest reducing the use of isotretinoin after bone injury or continuing the treatment at low dosing with a concomitant correction of vitamin D and calcium status.
\end{abstract}

Key words: isotretinoin, retinoids, bone fracture, bone healing.

\section{Introduction}

Isotretinoin has been the most effective drug for severe acne since its approval by the US Food and Drug Administration in May 1982. It belongs to retinoids which are derivatives of vitamin A. The drug targets all four major factors involved in the pathogenesis of acne, such as sebaceous gland hyperplasia with hyperseborrhea, follicular hyperkeratinization, hypercolonization of the pilosebaceous unit with Propionibacterium acnes and inflammation [1, 2].

There are at least several adverse effects which can preclude the use of isotretinoin and teratogenicity is the most important systemic toxicity. A fetal exposure to isotretinoin can contribute to severe skeletal defects in the baby [3]. A postnatal exposure of children to the drug may develop a premature closure of the lower-extremity growth plates with a later reduction in adult stature [4]. There is also a risk of diffuse skeletal hyperostosis in patients treated with isotretinoin [5]. On the other hand, isotretinoin was supposed to exert osteoporotic activity in bones [6, 7]. Overall, bone turnover is known to be altered by both vitamin A and its derivatives, which affect functioning of osteoclasts and osteoblasts $[8,9]$.
Undoubtedly, isotretinoin may affect different healing processes. Recently, a detrimental influence of isotretinoin on tissue regeneration after surgical procedures was shown to be mostly overestimated [10-12]. The management of patients on isotretinoin who experienced bone fracture remains however still unclear.

\section{Aim}

The aim of this review was to establish the safety of oral isotretinoin in patients with bone fracture.

\section{Material and methods}

Both Medline/PubMed and SCOPUS databases were searched to investigate the influence of isotretinoin on the skeletal system. Medical Subject Headings were applied in various combinations: isotretinoin, retinoids, alltrans retinoic acid, bone and bones, bone fractures, fracture healing, and bone density. Initially 833 records were found, but only 62 items were included in the final review. The authors analyzed only English papers published since 1995, but earlier manuscripts were cited when they had historic significance. Data were extracted with a focus on bone mineral density and metabolism, vitamin D

Address for correspondence: Beata Bergler-Czop MD, PhD, Department of Dermatology, School of Medicine, Medical University of Silesia, 20/24 Francuska St, 40-027 Katowice, Poland, phone: +48 32259 15 81, fax: +48 32 256 11 82, e-mail: bettina2@tlen.pl Received: 29.11.2017, accepted: 5.02.2018. 
and calcium status, bone repair, activity of osteoblasts and osteoclasts. Animal studies other than rodent ones were not analyzed. There were 11 human and 2 rat studies included in the major analysis of bone mineral density (BMD) and biochemical changes. Bone mineral density was analyzed only for the hip and the lumbar spine, but here rat studies were excluded due to distinct techniques of BMD measurement and short treatment protocol. Biochemical changes were analyzed in both human and rat studies. Three human and two rat case reports were extracted to present the only papers available in the English literature showing response of bones after an injury.

\section{Results and discussion}

\section{Osteoporotic effect of isotretinoin}

A high dietary intake of vitamin A was demonstrated to develop bone thinning in rats [8]. An excessive dietary intake of vitamin $A$ is known to increase a risk of osteoporotic bone fractures in humans [13-17]. Presumptively, isotretinoin exerts a negative impact on bone health (Table 1) and one should also expect a decrease of BMD in patients receiving oral isotretinoin. However, a significant change of BMD was seen neither at the lumbar spine nor at the hip in a cumulative number of 67 patients from three clinical studies [18-20]. The only study which showed a significant decrease of BMD at the hip on isotretinoin treatment was presented by Saadi et al., who however enrolled ten Emirati women only [21]. Another slight decrease in BMD at the hip was observed by Leachman et al. [22] and DiGiovanna et al. [6] but only when the density was measured at the Ward's triangle [22]. This area is currently not advisable for interpretation of BMD due to a large influence of positional changes [23], however one must expect an increase in femoral BMD rather than its anyway slight decrease in adolescents. A greater predisposition to a bone loss was seen in those patients with the lowest values of BMD before starting isotretinoin. Pretreatment evaluation of bone density seems to be therefore reasonable management before starting isotretinoin to identify those patients at greater risk of drug-induced osteoporosis [22]. Undoubtedly, this risk is much greater in females due to a concomitant use of oral contraceptives, which are known to have an unfavorable impact on the skeletal system [24, 25].

Four studies which analyzed a change of BMD at the lumbar spine in patients receiving oral isotretinoin showed its slight increase $(1.1-3.0 \%)$ in contrast to the reported decrease at long bones [6, 22, 26, 27]. This change remained however in a normal range for young adoles-

Table 1. Change of BMD in patients treated with isotretinoin (only human studies)

\begin{tabular}{|c|c|c|c|c|c|c|}
\hline \multirow[t]{2}{*}{ Authors } & \multirow{2}{*}{$\begin{array}{l}\text { Study } \\
\text { group }\end{array}$} & \multirow{2}{*}{$\begin{array}{l}\text { Control } \\
\text { group }\end{array}$} & \multirow{2}{*}{$\begin{array}{l}\text { Treatment protocol, birth control in females, } \\
\text { method of BMD analysis (device) }\end{array}$} & \multicolumn{2}{|c|}{ Mean change of BMD } & \multirow{2}{*}{$\begin{array}{l}\text { Other BMD } \\
\text { measurements }\end{array}$} \\
\hline & & & & Hip & Lumbar spine & \\
\hline $\begin{array}{l}\text { Tekin } \\
\text { et al. [20] }\end{array}$ & $\begin{array}{l}15 \mathrm{M} \\
21 \mathrm{~F}\end{array}$ & $\begin{array}{l}16 \mathrm{M} \\
20 \mathrm{~F}\end{array}$ & $\begin{array}{l}\text { - ISO until } 120 \mathrm{mg} / \mathrm{kg} \text { of the cumulative dose } \\
\text { - Contraception other than birth control pills only }\end{array}$ & NS & NS & \\
\hline $\begin{array}{l}\text { Kindmark } \\
\text { et al. [18] }\end{array}$ & $\begin{array}{l}9 \mathrm{M} \\
2 \mathrm{~F}\end{array}$ & N/A & - ISO 0.71-0.88 mg/kg daily for 6 months & - & NS & $\begin{array}{l}\text { No change of } \\
\text { total body BMD }\end{array}$ \\
\hline $\begin{array}{l}\text { Margolis } \\
\text { et al. [19] }\end{array}$ & $\begin{array}{l}6 \mathrm{M} \\
14 \mathrm{~F}\end{array}$ & $\mathrm{~N} / \mathrm{A}$ & $\begin{array}{l}\text { - ISO until } 122 \mathrm{mg} / \mathrm{kg} \text { of the cumulative dose } \\
\text { - birth control pills in } 10 \text { of } 14 \text { females }\end{array}$ & NS & NS & \\
\hline $\begin{array}{l}\text { Leachman } \\
\text { et al. [22] }\end{array}$ & $18 M$ & $14 \mathrm{M}$ & $\begin{array}{l}\text { - ISO } 1 \mathrm{mg} / \mathrm{kg} \text { daily for } 6 \text { months } \\
\text { - } 4 \text { persons showing the greatest decrease } \\
\text { in BMD at the Ward's triangle had lowest } \\
\text { baseline densities at the spine }\end{array}$ & $N S^{*}$ & $\begin{array}{c}1.1 \% \uparrow \\
(p=0.02)\end{array}$ & $\begin{array}{c}* 4.4 \% \downarrow(p=0.03) \\
\text { at the Ward's } \\
\text { triangle }\end{array}$ \\
\hline $\begin{array}{l}\text { Saadi } \\
\text { et al. [21] }\end{array}$ & $10 \mathrm{~F}$ & $\mathrm{~N} / \mathrm{A}$ & $\begin{array}{l}\text { - ISO until } 80.8 \pm 28.8 \mathrm{mg} / \mathrm{kg} \\
\text { - Two methods of contraception required }\end{array}$ & $\begin{array}{c}-5.3 \pm 1.9 \% \\
\downarrow \\
(p=0.002)\end{array}$ & NS & \\
\hline $\begin{array}{l}\text { DiGiovanna } \\
\text { et al. [6] }\end{array}$ & $\begin{array}{l}136 \mathrm{M} \\
81 \mathrm{~F}\end{array}$ & N/A & $\begin{array}{l}\text { - ISO } 1 \mathrm{mg} / \mathrm{kg} \text { daily until } 8821 \pm 2328 \mathrm{mg} \text { of the } \\
\text { cumulative dose }\end{array}$ & $\mathrm{NS}^{* *}$ & $\begin{array}{c}1.403 \pm 2.479 \% \\
\uparrow \\
(p<0.00001)\end{array}$ & $\begin{array}{l}{ }^{* *} 1.423 \pm 4.212 \% \\
\downarrow(p<0.00001) \\
\text { at the Ward's } \\
\text { triangle }\end{array}$ \\
\hline $\begin{array}{l}\text { Hoover } \\
\text { et al. [26] }\end{array}$ & $\begin{array}{l}289 \mathrm{M} \\
69 \mathrm{~F}\end{array}$ & N/A & $\begin{array}{l}\text { - ISO } 0.5 \mathrm{mg} / \mathrm{kg} \text { (first } 4 \text { weeks), } 1 \mathrm{mg} / \mathrm{kg} \\
\quad \text { (16 weeks) } \\
\text { - Oral contraceptives allowed }\end{array}$ & - & $\begin{array}{l}1.7-2.0 \% \uparrow \\
(p<0.0001)\end{array}$ & \\
\hline $\begin{array}{l}\text { Kocijancic } \\
{[27]}\end{array}$ & $15 M$ & $\mathrm{~N} / \mathrm{A}$ & $\begin{array}{l}\text { - ISO average total dose } 0.4 \mathrm{mg} / \mathrm{kg} \text { daily for } \\
6 \text { months }\end{array}$ & - & $3.0 \% \uparrow$ & \\
\hline $\begin{array}{l}\text { Erdogan } \\
\text { et al. [28] }\end{array}$ & $\begin{array}{l}14 \mathrm{M} \\
7 \mathrm{~F}\end{array}$ & $\begin{array}{l}10 \mathrm{M} \\
11 \mathrm{~F}\end{array}$ & - ISO until $120 \mathrm{mg} / \mathrm{kg}$ of the cumulative dose & NS & NS & \\
\hline
\end{tabular}

ISO - isotretinoin, $M$ - males, F-females, NS - non-significant, BMD - bone mineral density, N/A - not available. 
cents who typically manifest an increase in bone density $0.5-7.0 \%$ yearly [27]. Undoubtedly, one must look for artifacts such as confounding extraosseous calcification when assessing BMD at the lumbar spine in the anteroposterior view. Secondary adverse events such as longitudinal ligament calcification can lead to a paradoxical increase in $\mathrm{BMD}$, requiring a correction of measurements at this area [18, 23, 27, 28].

Although human studies showed only minimal influence of isotretinoin on bone density, animal studies demonstrated a more severe detrimental influence of retinoids on bone health. Recently, rats receiving intragastrically tazarotene $(0.075 \mathrm{mg} / \mathrm{kg})$ in sesame oil (4 ml/kg) daily were demonstrated to have worse bone mechanical properties than control animals. Both mean Young's modulus and the stiffness were significantly impaired at the femur in tazarotene-treated rats suggesting osteoporotic nature of the drug [29]. Previously, Hotchkiss et al. also demonstrated an unfavorable effect of retinoids in long bones. Both isotretinoin given in a daily dose of $7.5 \mathrm{mg} / \mathrm{kg}$ b.w. or $30 \mathrm{mg} / \mathrm{kg}$ b.w and ATRA in a daily dose of 10 or $15 \mathrm{mg} / \mathrm{kg}$ b.w. did reduce significantly bone mineral content and density at the femur. Femoral shaft diameter and bone marrow cavity were markedly smaller than in control subjects, although this detrimental effect was not seen in rats receiving low doses of isotretinoin. Histomorphometry showed a greater loss of both cortical and trabecular bone in animals treated with ATRA than in ones receiving isotretinoin. An inhibition of cortical bone expansion by retinoids is a unique effect since most of other drugs affect primarily remodeling of the trabecular bone. A progressively poorer quality of bones reduces their resistance to bending therefore predisposing to spontaneous long bone fractures that were reported in rats treated with ATRA [30].

\section{Retinoids and bone metabolism}

An analysis of biochemical markers of bone turnover after an exposure to isotretinoin showed mostly insignificant or only transient disturbances (Table 2). Two human studies showed a significant increase in serum parathyroid hormone, although in one of them (Kindmark et al.) this change was only transient [18, 31]. Bone alkaline phosphatase, a marker of bone formation was significantly increased in only one (Ertugrul et al.) of four human studies $[20,21,31,32]$ and in one rat study (Hotchkiss et al.) [30]. Other markers of bone formation,

Table 2. Biochemical changes following exposure to isotretinoin (7 human studies and 2 rat study)

\begin{tabular}{|c|c|c|c|c|c|c|c|c|c|c|c|c|}
\hline \multirow[t]{2}{*}{ Authors } & \multicolumn{2}{|c|}{ Vitamin D metabolites } & \multicolumn{3}{|c|}{$\begin{array}{l}\text { Markers of bone } \\
\text { formation }\end{array}$} & \multicolumn{4}{|c|}{ Markers of bone resorption } & \multicolumn{3}{|c|}{$\begin{array}{c}\text { Other markers of bone } \\
\text { turnover }\end{array}$} \\
\hline & $25(\mathrm{OH}) \mathrm{D}_{3}$ & $1,25(\mathrm{OH})_{2} \mathrm{D}_{3}$ & OC & PICP & BAP & $\begin{array}{l}\text { Urine DPD/ } \\
\text { serum PYD }\end{array}$ & $\begin{array}{l}\text { Urine } \\
\text { OHP }\end{array}$ & TRACP & $\begin{array}{l}\text { Urine } \\
\text { NTx }\end{array}$ & PTH & $\begin{array}{l}\text { Serum } \\
\text { calcium }\end{array}$ & $\begin{array}{c}\text { Serum } \\
\text { phosphate }\end{array}$ \\
\hline $\begin{array}{l}\text { Tekin } \\
\text { et al. [20] }\end{array}$ & - & - & $\uparrow(\mathrm{NS})$ & - & $\uparrow(N S)$ & $\uparrow(\mathrm{NS})$ & - & - & & $\uparrow(\mathrm{NS})$ & $\downarrow$ (NS) & $\downarrow$ (NS) \\
\hline $\begin{array}{l}\text { Leachman } \\
\text { et al. [22] }\end{array}$ & $\begin{array}{l}\uparrow(p= \\
0.02)\end{array}$ & $\uparrow(\mathrm{NS})$ & - & - & - & - & - & - & & $\uparrow(\mathrm{NS})$ & $\downarrow$ (NS) & $\uparrow(\mathrm{NS})$ \\
\hline $\begin{array}{l}\text { Kindmark } \\
\text { et al. [18] }\end{array}$ & - & - & $\downarrow$ ฟ & $\downarrow^{*}$ & $\downarrow$ (NS) & - & $\begin{array}{c}\uparrow \\
(\mathrm{NS})\end{array}$ & - & & 个* & $\downarrow^{*}$ & - \\
\hline $\begin{array}{l}\text { Margolis } \\
\text { et al. [19] }\end{array}$ & $\uparrow(N S)$ & $\downarrow(p=0.02)$ & $\uparrow(\mathrm{NS})$ & - & - & - & $\begin{array}{c}\uparrow \\
(\mathrm{NS})\end{array}$ & - & & $\uparrow(\mathrm{NS})$ & $\uparrow(\mathrm{NS})$ & $\downarrow$ (NS) \\
\hline $\begin{array}{l}\text { Saadi } \\
\text { et al. [21] }\end{array}$ & NS & - & - & - & NS & - & - & $\begin{array}{l}\uparrow(p< \\
0.001)\end{array}$ & & NS & $\begin{array}{c}\downarrow \\
(p=0.04)\end{array}$ & NS \\
\hline $\begin{array}{l}\text { Ertugrul } \\
\text { et al. [31] }\end{array}$ & $\begin{array}{c}\downarrow(p< \\
0.0001)\end{array}$ & $\uparrow(p<0.005)$ & - & - & $\begin{array}{c}\uparrow(p< \\
0.0001)\end{array}$ & - & - & - & & $\begin{array}{l}\uparrow(p< \\
0.005)\end{array}$ & $\begin{array}{c}\downarrow \\
(p<0.05)\end{array}$ & $\uparrow(\mathrm{NS})$ \\
\hline $\begin{array}{l}\text { Trifirò and } \\
\text { Norbiato } \\
{[32]}\end{array}$ & NS & NS & NS & & NS & - & - & - & $\begin{array}{l}\downarrow(p< \\
0.05)\end{array}$ & NS & - & - \\
\hline $\begin{array}{l}\text { Hotchkiss } \\
\text { et al. [30] } \\
\text { rat study }\end{array}$ & - & - & - & - & $\begin{array}{c}\uparrow * * \\
(p<0.05)\end{array}$ & NS change & - & - & & - & $\begin{array}{c}\uparrow * * * \\
(p<0.05)\end{array}$ & - \\
\hline $\begin{array}{l}\text { Bergoli } \\
\text { et al. [42] } \\
\text { rat study }\end{array}$ & - & - & - & - & - & - & - & - & & - & $\begin{array}{c}\downarrow^{\star * * *} \\
(p<0.05)\end{array}$ & - \\
\hline
\end{tabular}

NS - non-significant, OC-osteocalcin, PICP - procollagen type I carboxyl-terminal propeptide, BAP-bone alkaline phosphatase, PYD - pyridinoline, DPD - deoxypyridinoline, OHP - hydroxyproline, TRACP - tartrate-resistant acid phosphatase, PTH - parathyroid hormone, NTX - N-terminal telopeptide of type I collagen. *Transient change only within first 5 days, then normalized; **significant for all-trans-retinoic acid (ATRA), but not for isotretinoin; ***significant only for a high dose of isotretinoin, but not for ATRA; ${ }^{* * * *}$ significant at days 21,28 and 90 of isotretinoin administration. 
osteocalcin and procollagen type I carboxyl-terminal propeptide were rather transiently decreased within the first 5 days of therapy with isotretinoin in a study of Kindmark et al. [18].

Enhanced bone resorption was manifested by a significant increase in serum tartrate-resistant acid phosphatase in the study of Saadi et al. [21], whereas other markers (serum pyridinoline, urine deoxypyridinoline, urine hydroxyproline) were elevated insignificantly [19, 20, 22, 29]. Surprisingly, Trifiro and Norbiato found even a decrease in urine N-terminal telopeptide of type I collagen (NTx) level on isotretinoin treatment. NTx level correlates however with a degradation of type I collagen distributed both in the skeletal system and in the skin, thus different burdens of the skin may destroy collagen bundles with a consequent release of type I collagen degradation products. Treatment with isotretinoin probably limits this catabolism therefore decreasing the urine NTX level [32, 33].

Previously, hypercalcemia was postulated to have a dose-limiting toxic effect in patients receiving oral isotretinoin [34, 35] and ATRA [36-38]. This complication was also observed after an excessive use of over-thecounter supplements or enteral feeding formula containing vitamin A, especially in case of concomitant renal disease [39-41]. Only one (Hotchkiss et al.) from those reviewed studies showed a significant elevation of serum calcium, however exclusively in rats receiving a high-dose of isotretinoin [18, 20-22, 30, 31, 42]. Duncan et al. proposed controlling periodically serum calcium in those patients receiving a daily dose of isotretinoin greater than $1.3 \mathrm{mg} / \mathrm{kg}$ [43]. None of reviewed human studies showed any significant change of serum phosphate [20-22, 31].

\section{Retinoids and vitamin D}

A strong detrimental influence of vitamin A on bone mineralization in a low vitamin D supply was previously observed in rats [44]. An attenuation of vitamin D-dependent oral calcium absorption by an intense vitamin A supplementation was reported in both rats [44] and humans [45]. A Korean cross-sectional study showed however that an excessive intake of vitamin A had a negative impact on bone health only in a population with a vitamin $\mathrm{D}$ deficiency $\left(<50 \mathrm{nmol} / /\right.$ of $\left.25(\mathrm{OH}) \mathrm{D}_{3}\right)$ [46]. One must expect that optimal BMD may depend on the favorable ratio of vitamin $A$ intake to vitamin $D$ repletion or optimal ratio of serum retinol to 25 -hydroxyvitamin $D[47,48]$.

The vitamin $D$ deficiency was also reported to be a condition predisposing to increased bone resorption and decreased BMD in patients receiving isotretinoin [21]. There is a need for vitamin $D$ supplementation in children with ichthyotic disorders receiving oral acitretin, although a defective epidermal synthesis of vitamin D should be theoretically improved by oral retinoids [49]. A measurement of serum 25-hydroxyvitamin D and correction of vitamin $\mathrm{D}$ deficiency appear to be advisable before start- ing isotretinoin treatment for acne [47]. The National Osteoporosis Foundation recommends 400-800 international units (IU) of vitamin $D$ daily for most individuals aged under 50 and a need of 800-1,000 IU daily in most adults aged 50 and older. A supplementation of vitamin D at intakes over 4000 IU daily was previously shown to be safe management which effectively raises $25(\mathrm{OH}) \mathrm{D}$ to high-normal concentrations in most of adults [50].

\section{Retinoids and osteoblasts}

Normal osteoblast differentiation requires an upregulation of Cyp26b1, the major enzyme responsible for a degradation of retinoids [8]. An exposure to ATRA (panRAR-agonist) delays both differentiation and mineralization of osteoprogenitor cells into mature ones whereas a blockage of RAR receptors accelerates differentiation of early osteoprogenitors. A cessation of ATRA treatment is required to achieve a full expression of osteoblastic genes in osteogenic conditions. However, this inhibitory effect of ATRA appears to be long lasting and even after stopping a treatment, osteoprogenitor cells cannot retain a full differentiation capacity [51].

Retinoids downregulate expression of Phex, a protein which is necessary for mineralization of osteoblasts. A decrease in proteins Runx2 and Sp7 (Osterix) impairs mineralization and differentiation of osteoblasts. Both human osteoblasts and a murine preosteoblastic cell line have drastically reduced expression of alkaline phosphatase and osteocalcin, markers of osteoblast maturation, when treated with retinoids $[8,18]$.

Kneissel et al. showed that osteoblast performance following an exposure to retinoids depends on the cellular system. Retinoids manifest neither stimulatory nor inhibitory effect on pre-osteoblastic cell line MC3T3-E1, but they easily inhibit mouse primary calvarial osteoblasts [52]. Surprisingly, de Oliveira et al. demonstrated distinct observations. Isotretinoin at a daily dose of $7.5 \mathrm{mg} / \mathrm{kg}$ (an equivalent to the standard dose administered to humans in the treatment of severe acne $-1 \mathrm{mg} / \mathrm{kg} /$ day) did accelerate bone repair in rat calvaria, although this increase was not statistically significant [53].

\section{Retinoids and osteoclasts}

Retinoids were found to exert an inhibitory effect on osteoclastogenesis via RAR-gamma signaling [9]. There is a repression of RANKL stimulation with an ongoing decrease in c-Fos signaling pathway, therefore preventing from ongoing activation of NFAT [54]. NFAT promotes normal differentiation of osteoclasts from their precursor cells whereas an activation of RAR receptors delays this process [9]. The inhibitory effect starts already from early hematopoietic precursor cells located in bone marrow but retinoids can prevent from differentiation of those cells into mature osteoclasts. This effect occurs at a low concentration of retinoids when they do not even 
develop any morphological sings of cytotoxicity. Stimulatory influence of RANKL, M-CSF (macrophage colonystimulating factor) or vitamin $\mathrm{D}_{3}$ on hematopoietic cells is abolished by retinoids in a dose-dependent manner [54].

Skeletal effects of retinoids appear to depend on bone compartment. There is enhanced subperiosteal bone resorption in rats treated with retinoids, but this activity is reduced at the proximity to the bone marrow [52]. Presumptively, this increased bone resorption along the subperiosteal surface may explain bone loss under a treatment with retinoids [30]. Bone formation is decreased at the subperiosteal envelope, but it remains unaffected in the trabecular bone compartment. As a consequence, there is thinning of long bones due to the loss of cortical bone while bone length remains unaffected [52]. A similar compartment-dependent effect is also observed in rats with an excessive oral intake of vitamin $\mathrm{A}$, which develops a significant reduction in $\mathrm{mi}$ crovessels at the endosteal site therefore leading to bone marrow hypoxia. This condition activates osteoblasts at the endosteal/marrow compartment, which increases endosteal mineralization. An inverse tendency shows however osteoclasts which disappear at the endosteal compartment whereas their periosteal number starts to increase. Although hypervitaminotic A bones get thinner due to the increased periosteal osteoclastic activity, their stiffness is preserved since there is increased endosteal mineral deposition [55].

\section{Retinoids and bone repair}

There is a paucity of papers which report bone healing process after surgical interventions or injuries on isotretinoin treatment (Table 3). The maxillofacial area seems to respond with enhancement of new bone formation after exposure to isotretinoin. Soon after marketing of isotretinoin, Novick et al. reported bilateral nasal bone osteophytosis in a healthy woman who had undergone uneventful rhinoplasty 12 years earlier [56]. Much later, Allen and Rhee observed nasal tip complications (nasal tip asymmetry, alar collapse, prominence of composite graft cartilage) which developed within 6 months on isotretinoin treatment in three patients who had undergone rhinoplasty 2 years before [57]. Presumptively, this could be a superficial manifestation of diffuse skeletal hyperostosis or optionally, some periosteal tags (having osteogenic capacity) were stimulated by isotretinoin to undergo ossification [56]. Bergoli et al. observed also a stimulation of alveolar repair after tooth extraction in rats receiving isotretinoin. A new bone formation was greater and sockets were filled with compact bone earlier than control animals [42].

Human studies did not show any significant influence of systemic isotretinoin on healing after tooth extraction. Sharma et al. observed postoperative alveolar osteitis only in three of 26 subjects treated with isotretinoin who underwent surgical extraction of wisdom teeth but without long-term complications [58]. Molecular analysis showed however decreased activity of retinaldehyde dehydrogenase-2 (enzyme which produces endogenous retinoids in body tissue) in adult molars [59]. An inhibition of retinoic acid receptor $\gamma$ function was found to promote endochondral bone formation. Mice deprived of RAR- $\gamma$-signaling manifest a larger volume of cartilaginous tissue than wild type mice in a tibial bone defect model. An appearance of cartilaginous tissue is followed by a replacement with mineralized materials much higher than in control mice [60].

\section{Conclusions}

Isotretinoin was demonstrated to exert osteoporotic activity only in rat studies whereas this influence was not

Table 3. Studies reporting postsurgical skeletal effects under isotretinoin treatment

\begin{tabular}{|c|c|c|c|c|c|}
\hline Authors & Type of surgery & Subjects & $\begin{array}{l}\text { Control } \\
\text { subjects }\end{array}$ & $\begin{array}{l}\text { Time to isotretinoin treatment } \\
\text { operation }\end{array}$ & Skeletal effect \\
\hline $\begin{array}{l}\text { Novick et al. } \\
\text { [56] }\end{array}$ & Rhinoplasty & $1 \mathrm{~F}$ & N/A & 12 years after the procedure & $\begin{array}{l}\text { Nasal bone osteophytes noticeable } \\
\text { after } 5 \text { weeks of ISO treatment }\end{array}$ \\
\hline $\begin{array}{l}\text { Allen and } \\
\text { Rhee [57] }\end{array}$ & Septorhinoplasty & $2 \mathrm{~F}, 1 \mathrm{M}$ & $\mathrm{N} / \mathrm{A}$ & $\begin{array}{l}2 \text { years after }\left(1^{\text {st }} \text { case }\right), 7 \text { months after } \\
\left.\left(2^{\text {nd }} \text { case }\right), 1 \text { year after ( } 3^{\text {rd }} \text { case }\right)\end{array}$ & $\begin{array}{l}\text { Nasal tip asymmetry, alar collapse, } \\
\text { prominence of composite graft } \\
\text { cartilage, nasal tip bossae }\end{array}$ \\
\hline $\begin{array}{l}\text { Sharma et al. } \\
\text { [58] }\end{array}$ & $\begin{array}{l}\text { Third molar } \\
\text { surgery }\end{array}$ & 26 & $\mathrm{~N} / \mathrm{A}$ & $\begin{array}{l}\text { Current therapy with ISO or within } \\
3 \text { months of its discontinuation }\end{array}$ & $\begin{array}{l}\text { Dry socket only in } 3 \text { patients but } \\
\text { without long-term complications }\end{array}$ \\
\hline $\begin{array}{l}\text { de Oliveira } \\
\text { et al. [53] } \\
\text { rat study }\end{array}$ & $\begin{array}{l}2-\mathrm{mm} \text { cavity } \\
\text { drilled in rat } \\
\text { calvaria }\end{array}$ & 18 & 15 & $\begin{array}{l}18 \text { experimental rats receiving ISO } \\
\text { daily for } 30 \text { days prior to the surgical } \\
\text { procedure }\end{array}$ & $\begin{array}{l}\text { Acceleration of new bone } \\
\text { formation in rat calvaria by ISO }\end{array}$ \\
\hline $\begin{array}{l}\text { Bergoli et al. } \\
\text { [42] } \\
\text { rat study }\end{array}$ & $\begin{array}{l}\text { Tooth extraction } \\
\text { in rats }\end{array}$ & 20 & 12 & $\begin{array}{l}20 \text { experimental rats receiving daily } \\
\text { isotretinoin for } 30 \text { days prior to the } \\
\text { surgical procedure }\end{array}$ & $\begin{array}{l}\text { Acceleration of alveolar repair by } \\
\text { ISO }\end{array}$ \\
\hline
\end{tabular}

ISO-isotretinoin, $M-$ males, $F-$ females, N/A - not available. 
striking in humans. Undoubtedly, daily doses on a body weight in rats were much higher than the ones applicable for human patients. An intention was to generate quickly a concentration of the drug which would be achieved following an oral exposure to $0.5-1 \mathrm{mg} / \mathrm{kg}$ daily of isotretinoin for dermal conditions. Even here, an equivalent of a human daily dose of $1 \mathrm{mg} / \mathrm{kg}$ for isotretinoin did not develop marked changes in rat bones.

A change of bone turnover markers appears to be nothing but transient following an exposure to retinoids. The only mineral component which should be controlled is serum calcium in those patients receiving a daily dose of isotretinoin greater than $1.3 \mathrm{mg} / \mathrm{kg}$. Undoubtedly, a correction of vitamin D deficiency appears to be advisable management before starting isotretinoin to maintain a concentration of $25(\mathrm{OH}) \mathrm{D}_{3}$ on the moderate level of 50-75 nmol/l.

Several experimental studies showed however an unfavorable influence of retinoids on osteoblasts and osteoclasts functioning. An upregulation of enzymes responsible for degradation of retinoids in bone tissue was evidenced to be necessary to achieve a full mineralization of osteoblasts. Retinoids were shown to be also negative regulators of osteoclastogenesis and this effect starts already from early hematopoietic precursors. Overall, those findings confirm unfavorable influence of retinoids on bones since preserved activity of both cellular components is required to restore the original bone structure post fracture $[61,62]$.

Most of reviewed studies allow for only indirect conclusions regarding safety of isotretinoin treatment in patients who experienced bone fractures. Reports showing a direct influence of the drug on outcomes of surgical procedures in the skeletal system or bone healing process. The available ones show a facilitation of bone healing at the skull although with a risk of bone overgrowth. It is advisable to limit a use of isotretinoin before or soon after rhinoplasty surgery, whereas no similar necessity exists for dental interventions. Finally, the therapy with isotretinoin in patients who experienced a fracture of long bones may impair the healing process or develop bone thinning and osteoporotic structure. We suggest stopping isotretinoin treatment or at least reducing its dosing to only $0.5 \mathrm{mg} / \mathrm{kg}$ daily with a concomitant correction of vitamin D and calcium status.

One must remember that the therapy with isotretinoin can be complicated by acute rhabdomyolysis with a secondary impairment of long bone healing due to muscle weakness. Isotretinoin may affect any muscle in a random manner but muscle flaps in surrounding of a fracture are at greater risk of injury. A control of the creatine phosphokinase level to keep this below twice lower than the normal range seems to be required before any reconstructive surgery on bones [10].

\section{Conflict of interest}

The authors declare no conflict of interest.

\section{References}

1. Dessinioti C, Dreno B. Acne. In: European Handbook of Dermatological Treatments. Katsambas AD, Lotti TM, Dessinioti C, D’Erme AM (eds). Springer-Verlag, Berlin Heidelberg 2015; 3-17.

2. Bergler-Czop B, Brzezińska-Wcisło L. Pro-inflammatory cytokines in patients with various kinds of acne treated with isotretinoin. Postep Dermatol Alergol 2014; 31: 21-8.

3. Browne H, Mason G, Tang T. Retinoids and pregnancy: an update. Obstet Gynaecol 2014; 16: 7-11.

4. Noyes JJ, Levine MA, Belasco JB, Mostoufi-Moab S. Premature epiphyseal closure of the lower extremities contributing to short stature after cis-retinoic acid therapy in medulloblastoma: a case report. Horm Res Paediatr 2016; 85: 69-73.

5. Ling TC, Parkin G, Islam J, et al. What is the cumulative effect of long-term, low-dose isotretinoin on the development of DISH? Br J Dermatol 2001; 144: 630-2.

6. DiGiovanna JJ, Langman CB, Tschen EH, et al. Effect of a single course of isotretinoin therapy on bone mineral density in adolescent patients with severe, recalcitrant, nodular acne. J Am Acad Dermatol 2004; 51: 709-17.

7. Milstone LM, Insogna KL, Leachman SA. Isotretinoin does have an adverse effect on bone mineral density. J Am Acad Dermatol 2005; 53: 181.

8. Lind T, Sundqvist A, Hu L, et al. Vitamin a is a negative regulator of osteoblast mineralization. PLoS One 2013; 8: e82388.

9. Green AC, Poulton IJ, Vrahnas C, et al. RAR-gamma is a negative regulator of osteoclastogenesis. J Steroid Biochem Mol Biol 2015; 150: 46-53.

10. Ungarelli LF, Hetem CM, Farina Junior JA. Is it safe to operate on patients taking isotretinoin? Aesthetic Plast Surg 2016; 40: $139-48$.

11. Mahadevappa $\mathrm{OH}$, Mysore $\mathrm{V}$, Viswanath $\mathrm{V}$, et al. Surgical outcome in patients taking concomitant or recent intake of oral isotretinoin: a multicentric study-ISO-AIMS study. J Cutan Aesthet Surg 2016; 9: 106-14.

12. Larson DL, Flugstad NA, O'Connor E, et al. Does systemic isotretinoin inhibit healing in a porcine wound model? Aesthet Surg J 2012; 32: 989-98.

13. Melhus H, Michaëlsson K, Kindmark A, et al. Excessive dietary intake of vitamin $A$ is associated with reduced bone mineral density and increased risk for hip fracture. Ann Intern Med 1998; 129: 770-8.

14. Promislow JH, Goodman-Gruen D, Slymen DJ, Barrett-Connor E. Retinol intake and bone mineral density in the elderly: the Rancho Bernardo Study. J Bone Miner Res 2002; 17: 1349-58.

15. Feskanich D, Singh V, Willett WC, Colditz GA. Vitamin A intake and hip fractures among postmenopausal women. JAMA 2002; 287: 47-54.

16. Michaëlsson K, Lithell H, Vessby B, Melhus H. Serum retinol levels and the risk of fracture. N Engl I Med 2003; 348: 287-94.

17. Barker ME, Blumsohn A. Is vitamin A consumption a risk factor for osteoporotic fracture? Proc Nutr Soc 2003; 62: 845-50.

18. Kindmark A, Rollman O, Mallmin H, et al. Oral isotretinoin therapy in severe acne induces transient suppression of biochemical markers of bone turnover and calcium homeostasis. Acta Derm Venereol 1998; 78: 266-9.

19. Margolis DJ, Attie M, Leyden JJ. Effects of isotretinoin on bone mineralization during routine therapy with isotretinoin for acne vulgaris. Arch Dermatol 1996; 132: 769-74.

20. Tekin NS, Ozdolap S, Sarikaya S, Keskin SI. Bone mineral density and bone turnover markers in patients receiving a single course of isotretinoin for nodulocystic acne. Int J Dermatol 2008; 47: 622-5. 
21. Saadi H, Afandi B, Houssami L, et al. Effects of isotretinoin on bone turnover markers and bone mineral density in women with acne vulgaris and vitamin D deficiency: a preliminary study. Int J Diabetes Metabolism 2008; 16: 107-12.

22. Leachman SA, Insogna KL, Katz L, et al. Bone densities in patients receiving isotretinoin for cystic acne. Arch Dermatol 1999; 135: 961-5.

23. Garg MK, Kharb S. Dual energy X-ray absorptiometry: pitfalls in measurement and interpretation of bone mineral density. Indian J Endocrinol Metab 2013; 17: 203-10.

24. Biason TP, Goldberg TB, Kurokawa CS, et al. Low-dose combined oral contraceptive use is associated with lower bone mineral content variation in adolescents over a 1-year period. BMC Endocr Disord 2015; 15: 15.

25. Scholes D, Hubbard RA, Ichikawa LE, et al. Oral contraceptive use and bone density change in adolescent and young adult women: a prospective study of age, hormone dose, and discontinuation. J Clin Endocrinol Metab 2011; 96: E1380-7.

26. Hoover KB, Miller CG, Galante NC, Langman CB. A double-blind, randomized, phase III, multicenter study in 358 pediatric subjects receiving isotretinoin therapy demonstrates no effect on pediatric bone mineral density. Osteoporos Int 2015; 26: 2441-7.

27. Kocijancic M. 13-cis-retinoic acid and bone density. Int J Dermatol 1995; 34: 733-4.

28. Erdogan BS, Yüksel D, Aktan S, et al. The effects of isotretinoin treatment on bone mineral density in patients with nodulocys tic acne. J Eur Acad Dermatol Venereol 2006; 20: 1006-7.

29. Nowak B, Matuszewska A, Filipiak J, et al. The negative impact of selective activation of retinoic acid receptors on bone metabolism and bone mechanical properties in rats. Adv Clin Exp Med 2016; 25: 213-8.

30. Hotchkiss CE, Latendresse J, Ferguson SA. Oral treatment with retinoic acid decreases bone mass in rats. Comp Med 2006; 56: 502-11.

31. Ertugrul DT, Karadag AS, Tutal E, Akin KO. Therapeutic hotline. Does isotretinoin have effect on vitamin D physiology and bone metabolism in acne patients? Dermatol Ther 2011; 24: 291-5.

32. Trifirò G, Norbiato G. Type I collagen N-telopeptide variation in adolescents receiving oral isotretinoin for severe acne. J Pediatr Endocrinol Metab 2002; 15: 35-9.

33. Bergler-Czop B, Miziołek B. Aging - what do we know? Acta Dermatovenerol Croat 2015; 25: 50-6.

34. Valentic JP, Elias AN, Weinstein GD. Hypercalcemia associated with oral isotretinoin in the treatment of severe acne. JAMA 1983; 250: 1899-900.

35. Villablanca JG, Khan AA, Avramis VI, Reynolds CP. Hypercalcemia: a dose-limiting toxicity associated with 13-cis-retinoic acid. Am J Pediatr Hematol Oncol 1993; 15: 410-5.

36. Lemez P. Hypercalcaemia caused by all-trans retinoic acid (ATRA) treatment in a case of acute promyelocytic leukaemia was manageable after decreasing the ATRA dose to $27 \mathrm{mg} / \mathrm{m} 2 /$ day. Eur J Haematol 1995; 55: 275-6.

37. Cordoba R, Ramirez E, Lei SH, et al. Hypercalcemia due to an interaction of all-trans retinoic acid (ATRA) and itraconazole therapy for acute promyelocytic leukemia successfully treated with zoledronic acid. Eur J Clin Pharmacol 2008; 64: 1031-2.

38. Hisatake J, Shimozuma J. Hypercalcemia associated with alltrans retinoic acid therapy for microgranular type acute promyelocytic leukemia. Rinsho Ketsueki 2008; 49: 408-12.

39. Baxi SC, Dailey GE. Hypervitaminosis A. A cause of hypercalcemia. West J Med 1982; 137: 429-31

40. Cohen EP, Trivedi C. Hypercalcaemia from non-prescription vitamin A. Nephrol Dial Transplant 2004; 19: 2929.
41. Bhalla K, Ennis DM, Ennis ED. Hypercalcemia caused by iatrogenic hypervitaminosis A. J Am Diet Assoc 2005; 105: 119-21.

42. Bergoli RD, Chagas Junior OL, de Souza CE, et al. Isotretinoin effect on alveolar repair after exodontias: a study in rats. Oral Maxillofac Surg 2011; 15: 85-92.

43. Duncan WE, Guill M, Aton J. Serum calcium concentrations during treatment with isotretinoin. J Am Acad Dermatol 1986; 14: 1096.

44. Rohde CM, Manatt M, Clagett-Dame M, DeLuca HF. Vitamin A antagonizes the action of vitamin D in rats. J Nutr 1999; 129: 2246-50.

45. Johansson S, Melhus H. Vitamin A antagonizes calcium response to vitamin D in man. J Bone Miner Res 2001; 16: 1899905.

46. Joo NS, Yang SW, Song BC, Yeum KJ. Vitamin A intake, serum vitamin $D$ and bone mineral density: analysis of the Korea National Health and Nutrition Examination Survey (KNHANES, 2008-2011). Nutrients 2015; 7: 1716-27.

47. Boucher BJ. Serum retinol levels and fracture risk. N Engl J Med 2003; 348: 1927-8.

48. Chandra RK. Serum retinol levels and fracture risk. N Engl J Med 2003; 348: 1927-8.

49. Neema S, Mukherjee S, Vasudevan B, et al. Vitamin D deficiency after oral retinoid therapy for ichthyosis. Pediatr Dermatol 2015; 32: e151-5.

50. Vieth R, Chan PC, MacFarlane GD. Efficacy and safety of vitamin D3 intake exceeding the lowest observed adverse effect level. Am J Clin Nutr 2001; 73: 288-94.

51. Green AC, Kocovski P, Jovic T, et al. Retinoic acid receptor signalling directly regulates osteoblast and adipocyte differentiation from mesenchymal progenitor cells. Exp Cell Res 2017; 350: 284-97.

52. Kneissel M, Studer A, Cortesi R, Susa M. Retinoid-induced bone thinning is caused by subperiosteal osteoclast activity in adult rodents. Bone 2005; 36: 202-14.

53. de Oliveira HT, Bergoli RD, Hirsch WD, et al. Isotretinoin effect on the repair of bone defects - a study in rat calvaria. J Craniomaxillofac Surg 2013; 41: 581-5.

54. Conaway HH, Persson E, Halén M, et al. Retinoids inhibit differentiation of hematopoietic osteoclast progenitors. FASEB J 2009; 23: 3526-38

55. Lind $T$, Lind $P M$, Jacobson $A$, et al. High dietary intake of retinol leads to bone marrow hypoxia and diaphyseal endosteal mineralization in rats. Bone 2011; 48: 496-506.

56. Novick NL, Lawson W, Schwartz IS. Bilateral nasal bone osteophytosis associated with short-term oral isotretinoin therapy for cystic acne vulgaris. Am J Med 1984; 77: 736-9.

57. Allen BC, Rhee JS. Complications associated with isotretinoin use after rhinoplasty. Aesthetic Plast Surg 2005; 29: 102-6.

58. Sharma J, Thiboutot DM, Zaenglein AL. The effects of isotretinoin on wisdom tooth extraction. J Am Acad Dermatol 2012; 67: 794-5.

59. Berkovitz BK, Maden M, McCaffery P, Barrett AW. The distribution of retinaldehyde dehydrogenase- 2 in rat and human orodental tissues. Arch Oral Biol 2001; 46: 1099-104.

60. Uchibe K, Son J, Larmour C, et al. Genetic and pharmacological inhibition of retinoic acid receptor gamma function promotes endochondral bone formation. J Orthop Res 2017; 35: 1096-105.

61. Tanaka Y, Nakayamada S, Okada Y. Osteoblasts and osteoclasts in bone remodeling and inflammation. Curr Drug Targets Inflamm Allergy 2005; 4: 325-8.

62. Crockett JC, Rogers MJ, Coxon FP, et al. Bone remodelling at a glance. J Cell Sci 2011; 124: 991-8. 